\title{
ПОЛИЦЕЙСКОЕ ПРИНУЖДЕНИЕ
}

Лапина М.А., Карпухин Д.В.

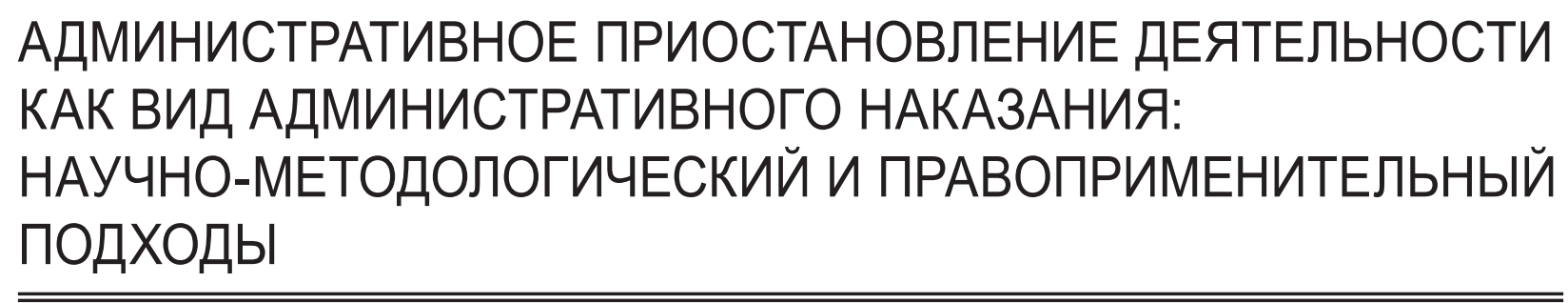

Аннотация: Предметом статьи являются действующие нормы Кодекса Российской Федерации об административных правонарушениях, регламентирующих понятие административного приостановления деятельности как вида административного наказания, а также материалы судебной практики Верховного Суда РФ, Высшего Арбитражного Суда РФ, содержащие нормативные толкования данного вида административной ответственности. Этот вид наказания назначается исключительно в судебном порядке на срок до 90 суток. Назначение данной санкции обусловлено рядом чрезвычайных обстоятельств, несущих угрозу жизни и здоровью людей, эпидемии, эпизоотии и т.д. Однако анализ правовых предписаний Кодекса Российской Федерации об административных правонарушениях свидетельствует, что данный вид административного наказания часто выступает в качестве альтернативы иным видам административного наказания - административному штрафру и конфискации. Исследуется правовая природа данной санкции, реальная цель которой заключается в немедленном прекращении противоправных действий со стороны субъекта нарушающего правовые предписания. Методологическую основу статьи составили современные достижения теории познания. В процессе исследования применялись общефилософрский, теоретический, общефрилософрские методы (диалектика, системный метод, анализ, синтез, аналогия, дедукция, наблюдение, моделирование), традиционно правовые методы (формально-логический), а также методы, используемые в конкретно-социологических исследованиях (статистические, экспертные оценки и др.). Основной вывод, который делают авторы заключается в том, что необходимо исключить данный вид административного наказания из санкций главы 14 КоАП РФ, так как применение данного вида наказания противоречит его административно-пресекательной правовой природе и стимулирует коррупциогенные риски. Основным вкладом, который сделан авторами, является комплексное исследование научно-методологических подходов и материалов судебной практики, выявление ярко выраженной административно-пресекательного характера данной меры административного принуждения. Новизна статьи заключается 
в разработке предложений по оптимизации административных санкций, содержащихся в главе 14 КоАП РФ.

Ключевые слова: Юридическая санкция, административное наказание, государственное принуждение, мера административного принуждения, предупредительные меры, пресекательные меры, наказательные меры, административное приостановление деятельности, временный запрет деятельности, административный штраф.

Review: The article focuses on the current norms of the Code of Administrative Offences of the Russian Federation, regulating the notion of administrative suspension of activity as a form of administrative punishment, as well as the materials of judicial practice of the Supreme Court of the Russian Federation and the Supreme Arbitration Court of the Russian Federation, containing the normative interpretations of this form of administrative liability. This form of punishment is inflicted only in a judicial proceeding for up to 90 days. Imposition of this sanction is determined by emergencies, threatening life and health of people, epidemic, epizootic, etc. However, the analysis of legal requirements of the Code of Administrative Offences of the Russian Federation indicates that this form of administrative punishment is often used as an alternative to other forms of administrative punishment - administrative fines and confiscation. The authors study the legal nature of this sanction, the real purpose of which is an immediate cessation of illegal actions on the part of the subject, infringing legal regulations. The methodological basis for the article contains the recent achievements of epistemology. The authors apply general philosophical and theoretical methods (dialectics, the systems method, analysis, synthesis, analogy, deduction, observation, modeling), traditional legal methods (formal logical), and the methods of specific sociological studies (statistical, expert evaluation, etc.).The authors conclude that it is necessary to exclude this form of administrative punishment from the sanctions of Chapter 14 of the Code of Administrative Offences, since the application of this punishment contradicts its administrative and preclusive legal nature and stimulates corruptogenic risks. The main contribution of the authors is a comprehensive study of scientific and methodological approaches and materials of judicial practice, revealing the pronounced administrative-preclusive nature of this measure of administrative coercion. The novelty of the article lies in the proposals on optimization of administrative sanctions provided in Chapter 14 of the Code of Administrative Offences of the Russian Federation.

Keywords: Administrative suspension of activity, measures of punishment, preclusive measures, preventive measures, administrative coercive measure, state coercion, administrative punishment, legal sanction, temporary prohibition of activity, administrative penalty.

Статья подготовлена по результатам исследований, выполненных за счёт бюджетных средств по государственному заданию Финуниверситета 2015 года.

Статья написана с использованием СПС «Консультант» 
$\mathrm{H}$ ормативно-правовым аспектам и вопросам практики правоприменения административных наказаний в науке административно-деликтного права уделяется повышенное внимание. Несмотря на то, что административные наказания налагаются за административные проступки, не отличающиеся повышенной степенью социальной опасности (вредности), правовая характеристика видов административных наказаний, содержащихся в КоАП РФ различается как по субъекту, уполномоченному на их наложение, так и по потенциальным негативным последствиям для юридических лиц и индивидуальных предпринимателей, в отношении которых применяются конкретные административные наказания, например, административное приостановление деятельности. Как справедливо отмечает Н.Г. Салищева в статье «О некоторых тенденциях развития законодательства об административной ответственности в России в современный период», «такие административные наказания как административный арест, административное приостановление деятельности и даже дисквалификация, являются санкциями, назначаемыми в исключительных случаях, когда применение иных мер не представляется возможным» [1]. Учёный считает, что законодатель должен очень осторожно подходить к предложениям о расширении сореры подобных санкций, а судебная практика - к их применению. «Известны многочисленные случаи, пишет Н.Г. Салищева, - когда судьи районных судов выносят постановления об административном приостановлении деятельности таких социально значимых объектов, как общежития, психоневрологические больницы, школы, руководствуясь материалами проверок соответству- ющих контрольно-надзорных органов. При этом они далеко не всегда остро реагируют на создавшиеся ситуации путем вынесения представлений, адресованных местной администрации, об устранении причин и условий, способствовавших совершению административных правонарушений, и не выясняют, почему должностные лица государственного пожарного надзора, Роспотребнадзора и других надзорных ведомств не применили таких пресекательно-предупредительных мер, как временный запрет деятельности конкретного объекта или его части ... также в качестве исключительной меры (ст. 27.16 и 27.17 КоАП РФ)»[1].

В статье «Проблемы правового регулирования института административной ответственности в Российской Федерации» Н.Г. Салищева высказывает точку зрения, что нормы КоАП РФ, предусматривающие административные наказания юридических лиц, индивидуальных предпринимателей в виде административного приостановления их деятельности нуждаются в серьёзном осмыслении[2]. Автор отмечает, что тенденция ужесточения административных наказаний в виде административного приостановления деятельности сохраняется и поныне[2]. «Достаточно проанализировать, - пишет учёный, - изменения ст. 3.12 КоАП РФ с точки зрения сфреры применения наказания в виде административного приостановления деятельности. В течение 2006 - 2013 гг. в ч. 1 ст. 3.12 КоАП РФ восемь раз вносились изменения, касающиеся расширения сферы круга деликтов, в отношении которых возможно применение такой санкции. Это касается общественных отношений в сорере охраны общественного порядка, в области градостроительства, в области продажи билетов на спортивные мероприятия Олимпийских игр и др. Представляется, 
что столь широкое применение административного приостановления может негативно сказаться на предпринимательской деятельности, свобода которой гарантируется Конституцией РФ ... нужно критически пересмотреть те статьи Особенной части КоАП РФ (их ныне более 50), которые предусматривают такое административное наказание»[2].

Обращение видного отечественного учёного-административиста к анализу проблемы назначения административного наказания в виде административного приостановления деятельности обусловлено повышенным общественным вниманием предпринимательского сообщества к данной санкции, так как её применение сопряжено, по сути, с прекращением хозяйственной деятельности юридического лица (индивидуального предпринимателя) и значительными финансовыми потерями, включая упущенную выгоду.

Административное приостановление деятельности как вид административного наказания установлен пунктом 9 частью 1 статьи 3.2 КоАП РФ. Данный вид административного наказания был введён в действующий КоАП РФ в 2005 году[3]. Однако следует заметить, что в судейском сообществе проект введения данного вида административного наказания вызвал неоднозначную реакцию. Так, ещё до принятия Федерального закона от 9 мая 2005 г. № 45-Ф3 Высший Арбитражный Суд Российской Федерации обращал внимание на то, что административное приостановление деятельности, предлагаемое для включения в КоАП РФ «не отвечает критериям наказания, а является мерой пресекательно-обеспечительного принуждения», поскольку ее основной задачей является пресечение административного деликта и обеспечение производства по делу, а не карательная функция, что более характерно для административного наказания [4].

Сущность данного вида наказания, срок и круг субъектов, уполномоченных возлагать данную санкцию, определён в статье 3.12 КоАП РФ. Так, часть 1 указанной статьи определяет данный вид наказания как временное прекращение деятельности лиц, осуществляющих предпринимательскую деятельность без образования юридического лица, юридических лиц, их фрилиалов, представительств, структурных подразделений, производственных участков, а также эксплуатации агрегатов, объектов, зданий или сооружений, осуществления отдельных видов деятельности (работ), оказания услуг.

Административное приостановление деятельности назначается судьёй, за исключением случаев, предусмотренных частью 3 статьи 9.1 КоАП РФ (в части грубого нарушения требований промышленной безопасности). В указанном случае административное приостановление деятельности назначается должностными лицами, указанными в пунктах 1 и 4 части 2 статьи 23.31 КоАП РФ. К их числу относятся руководитель федерального органа исполнительной власти, осуществляющего федеральный государственный надзор в области промышленной безопасности, федеральный государственный надзор в области безопасности гидротехнических сооружений, государственный горный надзор, его заместители; руководители территориальных органов фредерального органа исполнительной власти, осуществляющего федеральный государственный надзор в области промышленной безопасности, федеральный государственный надзор в области безопасности гидротехнических сооружений, государственный горный надзор, их заместители. 
Административное приостановление деятельности устанавливается на срок до девяноста суток (ч. 2 ст. 3.12 КоАП РФ).

Административное приостановление деятельности применяется в случае угрозы жизни или здоровью людей, возникновения эпидемии, эпизоотии, заражения (засорения) подкарантинных объектов карантинными объектами, наступления радиационной аварии или техногенной катастрофы, причинения существенного вреда состоянию или качеству окружающей среды либо в случае совершения административного правонарушения в области оборота наркотических средств, психотропных веществ и их прекурсоров, растений, содержащих наркотические средства или психотропные вещества либо их прекурсоры, и их частей, содержащих наркотические средства или психотропные вещества либо их прекурсоры, в области противодействия легализации (отмыванию) доходов, полученных преступным путем, и финансированию терроризма, в области установленных в соответствии с федеральным законом в отношении иностранных граждан, лиц без гражданства и иностранных организаций ограничений на осуществление отдельных видов деятельности, в области правил привлечения иностранных граждан и лиц без гражданства к трудовой деятельности, осуществляемой на торговых объектах (в том числе в торговых комплексах), в области порядка управления, в области общественного порядка и общественной безопасности, в области производства и оборота этилового спирта, алкогольной и спиртосодержащей продукции, в области градостроительной деятельности, в области транспортной безопасности, в области охраны собственности, а также в случае совершения административного правонарушения, посягающего на здоровье, санитарно-эпидемиологическое благополучие населения и общественную нравственность (часть 1 ст. 3.12 КоАП РФ).

Важные разъяснения по вопросу применения данной меры административного наказания содержатся в Постановлении Пленума Верховного Суда Российской Федерации от 24 марта 2005 г. № 5 «О некоторых вопросах, возникающих при применении Кодекса Российской Федерации об административных правонарушениях» (ред. от 19.12.2013)[5].

В пункте 23.3 указанного Постановления Верховного Суда РФ отмечено, что наказание в виде административного приостановления деятельности индивидуального предпринимателя или юридического лица может быть назначено судьей районного суда лишь в случаях, предусмотренных статьями Особенной части КоАП РФ, если менее строгий вид наказания не сможет обеспечить достижение цели административного наказания, что должно быть мотивировано в постановлении по делу об административном правонарушении (абзац второй части 1 статьи 3.12, пункт 6 части 1 статьи 29.10 КоАП РФ). При назначении этого наказания надлежит учитывать характер деятельности индивидуального предпринимателя или юридического лица, характер совершенных ими действий (бездействия), а также другие обстоятельства, влияющие на создание условий для реальной возможности наступления негативных последствий для жизни или здоровья людей, возникновения эпидемии, эпизоотии, заражения (засорения) подкарантинных объектов карантинными объектами, наступления радиационной аварии или техногенной 
катастрофы, причинения существенного вреда состоянию или качеству окружающей среды (абзац первый части 1 статьи 3.12 КоАП РФ). Обстоятельства, создающие, по мнению судьи, угрозу причинения вреда, должны быть указаны им в постановлении по делу об административном правонарушении.

Определяя срок административного приостановления деятельности, необходимо иметь в виду, что он не может превышать девяноста суток, включая срок временного запрета деятельности индивидуального предпринимателя или юридического лица, если такая мера обеспечения производства по делу об административном правонарушении применялась (часть 2 статьи 3.12, часть 5 статьи 29.6 КоАП РФ). В случае применения названной меры судье следует отразить это обстоятельство в постановлении по делу, включая время фактического прекращения деятельности, указанное в протоколе о временном запрете деятельности (часть 3 статьи 27.16 КоАП РФ). Время начала и окончания срока административного приостановления деятельности индивидуального предпринимателя или юридического лица не должно определяться в постановлении, так как это не предусмотрено КоАП РФ.

В постановлении по делу судья обязан решить вопрос о мероприятиях, необходимых для обеспечения его исполнения, которые в зависимости от обстоятельств каждого дела могут заключаться во временном прекращении эксплуатации тех агрегатов, объектов, зданий или сооружений, принадлежащих индивидуальному предпринимателю или юридическому лицу, либо во временном прекращении осуществления индивидуальным предпринимателем или юридическим лицом, его филиалами, представительствами, структурными подразделениями, производственными участками тех видов деятельности (работ), оказания услуг, от которых исходит угроза причинения вреда охраняемым общественным отношениям (абзац второй части 2 статьи 29.10 КоАП РФ).

Таким образом, Кодекс Российской Федерации об административных правонарушениях акцентирует внимание на исключительном, чрезвычайном характере данного вида административного наказаний, что, по нашему мнению, предполагает безальтернативность данного вида наказания при принятии решения судом о его назначении. На наш взгляд, в качестве авторской аргументации по данному вопросу могут быть использованы положения части 1 статьи 3.12 КоАП РФ о том, что административное приостановление деятельности назначается только в случаях, предусмотренных статьями Особенной части настоящего Кодекса, если менее строгий вид административного наказания не сможет обеспечить достижение цели административного наказания (часть 1 ст.3.12 КоАП РФ).

В аналогичном смысловом контексте выдержан другой акт официального толкования права - Постановление Пленума Высшего арбитражного суда Российской Федерации от 2 июня 2004 г. № 10 «О некоторых вопросах, возникших в судебной практике при рассмотрении дел об административных правонарушениях» (далее - Постановление Пленума ВАС РФ) [6]. Так, в пункте 18.2 указанного Постановления (введен Постановлением Пленума ВАС РФ от 10.11.2011 N 71) отмечено, что суд, исходя из нормы, предусмотренной абзацем вторым части 1 статьи 3.12 КоАП РФ, рассматривая 
дело об административном правонарушении, за совершение которого соответствующей статьей (частью статьи) КоАП РФ установлена в качестве альтернативы санкция в виде административного приостановления деятельности, должен при вынесении решения о наложении административного наказания в виде административного приостановления деятельности указать в мотивировочной части решения мотивы, по которым считает, что менее строгий вид административного наказания не сможет обеспечить достижение цели административного наказания[6,7].

Кроме того, в Постановлении Пленума ВАС РФ от 02.06.2004 № 10 разъяснено, что исходя из положений второго пункта части 1 статьи 3.12 и пункта 2 части 1 статьи 30.7 КоАП РФ суд апелляционной или кассационной инстанции, рассматривая жалобу на решение суда первой инстанции, которым лицо привлечено к административной ответственности с назначением ему иного наказания, нежели административное приостановление деятельности, не вправе изменить решение, назначив лицу наказание в виде административного приостановления деятельности.

Таким образом, в рассматриваемом акте официального толкования права санкция в виде административного приостановления деятельности рассматривается как наиболее суровый вид административного наказания, по отношению к иным наказаниям, сорормулированным в альтернативных санкциях Особенной части КоАП РФ.

Анализ положений, содержащихся в актах официального толкования права, позволяет сделать вывод о том, что судебная власть делает акцент на сужение сореры применения административ- ного наказания в виде административного приостановления деятельности, подчеркивая исключительный характер данного вида наказания.

Однако нормотворческая тенденция развития административного законодательства свидетельствует об обратном. В настоящее время в Государственную Думу Федерального Собрания Российской Федерации внесён проект Федерального закона N 703192-6 «Кодекс Российской Федерации об административных правонарушениях (Общая часть)» (далее - проект КоАП РФ (общая часть) [8] .

Часть 1 статьи 4.2 проекта КоАП РФ (общая часть) содержит закрытый перечень видов административного наказаний и предусматривает административное наказание в виде административного приостановления деятельности. Положения статьи 4.16 проекта КоАП РФ (общая часть) по многим позициям дублируют положения действующих положений статьи 3.12 КоАП РФ. В частности, срок действия данной меры административного наказания может составлять до 90 (девяноста) суток; данная санкция назначается только судом в отношении юридических лиц, и лиц, осуществляющих предпринимательскую деятельность без образования юридического лица. Зафиксирован исключительный характер данного наказания, заключающийся в том, что административное приостановление деятельности может быть назначено только в том случае, если менее строгий вид административного наказания не сможет обеспечить достижение цели административного наказания (часть 2 статьи 4.16) [8].

Таким образом, можно прогнозировать сохранение данного вида административного наказания в системе административ- 
но-наказательных мер государственного принуждения Российской Федерации.

Анализ административных наказаний, налагаемых за совершение административных правонарушений, содержащихся в главе 14 КоАП РФ «Административные правонарушения в области предпринимательской деятельности и саморегулируемых организаций» показывает, что большинство содержащихся в ней санкций, предусматривающих наказания в виде административного приостановления деятельности, носят альтернативный характер, что предполагают возможность выбора определённого вида административного наказания по усмотрению суда, уполномоченного налагать данный вид наказания на хозяйствующего субъекта в лице юридического лица или индивидуального предпринимателя. По мнению авторов настоящей статьи, сама постановка вопроса о возможности судебного усмотрения при выборе административной санкции, одной из которой является административное приостановление деятельности девальвирует исключительный, чрезвычайный характер данного вида административного наказания; повышает коррупциогенные риски при принятии судебного решения; несёт высокие потенциальные риски финансовых потерь для предпринимателей.

К указанным составам относятся:

Часть 4 статьи 14.1 (осуществление предпринимательской деятельности с грубым нарушением условий, предусмотренных специальным разрешением (лицензией)).

Административное приостановление деятельности может быть наложено на лиц, осуществляющих предпринимательскую деятельность и юридических лиц в качестве альтернативы штрафру.
Часть 4 статьи 14.1.1 (осуществление деятельности по организации и проведению азартных игр в букмекерских конторах и тотализаторах с грубым нарушением условий, предусмотренных лицензией).

Административное приостановление деятельности может быть наложено на юридических лиц в качестве альтернативы штрафу.

Часть 2 статьи 14.1.2 (повторное совершение административного правонарушения, предусмотренного частью 1 настоящей статьи, (осуществление предпринимательской деятельности в области транспорта без лицензии)).

Административное приостановление деятельности может быть наложено на юридических лиц в качестве альтернативы штрафу с конфискацией транспортного средства.

Часть 4 статьи 14.1.2 (осуществление предпринимательской деятельности в области транспорта, за исключением автомобильного транспорта и городского наземного электрического транспорта, с грубым нарушением условий, предусмотренных лицензией).

Административное приостановление деятельности может быть наложено на юридических лиц в качестве альтернативы штрафу.

Часть 2 статья 14.17 (производство или оборот этилового спирта, алкогольной и спиртосодержащей продукции с грубым нарушением лицензионных требований, предусмотренных законодательством о государственном регулировании производства и оборота этилового спирта, алкогольной и спиртосодержащей продукции и об ограничении потребления (распития) алкогольной продукции).

Административное приостановление деятельности с конфискацией может быть наложено на юридических лиц 
в качестве альтернативы штрафу с конфискацией.

Статья 14.18 (использование этилового спирта, произведенного из непищевого сырья, и спиртосодержащей непищевой продукции для приготовления алкогольной и спиртосодержащей пищевой продукции).

Административное приостановление деятельности может быть наложено на юридических лиц в качестве альтернативы штрафу с конфискацией произведенной продукции.

Часть 3 статьи 14.43 (повторное совершение административного правонарушения, предусмотренного данной статьи (нарушение изготовителем, исполнителем (лицом, выполняющим функции иностранного изготовителя), продавцом требований технических регламентов или подлежащих применению до дня вступления в силу соответствующих технических регламентов обязательных требований к продукции либо к продукции и связанным с требованиями к продукции процессам проектирования (включая изыскания), производства, строительства, монтажа, наладки, эксплуатации, хранения, перевозки, реализации и утилизации либо выпуск в обращение продукции, не соответствующей таким требованиям, за исключением случаев, предусмотренных статьями $6.31,9.4,10.3,10.6,10.8$, частью 2 статьи 11.21, статьями 14.37, 14.44, 14.46, 14.46.1, 20.4 КоАП РФ, повлекшие причинение вреда жизни или здоровью граждан, имуществу фризических или юридических лиц, государственному или муниципальному имуществу, окружающей среде, жизни или здоровью животных и растений либо создавшие угрозу причинения вреда жизни или здоровью граждан, окружаю- щей среде, жизни или здоровью животных и растений)).

Административное приостановление деятельности с конфискацией может быть наложено на лиц, осуществляющих предпринимательскую деятельность без образования юридического лица, и юридических лиц в качестве альтернативы штрафу с конфискацией.

Часть 2 статьи 14.54 устанавливает за «совершение административного правонарушения, предусмотренного частью 1 данной статьи (нарушение организацией, проводившей специальную оценку условий труда), установленного порядка проведения специальной оценки условий труда, лицом, ранее подвергнутым административному наказанию за аналогичное административное правонарушение» санкцию в виде административного приостановления деятельности. Она применяется в отношении юридических лиц в качестве альтернативы штрафу.

Часть 2 статьи 14.58 (Повторное совершение административного правонарушения, предусмотренного частью 1 настоящей статьи (осуществление проката фильма и (или) показа фрильма без прокатного удостоверения на фильм, если такое удостоверение требуется в соответствии с фредеральным законом, или нарушение установленного в прокатном удостоверении способа использования фрильма)) аналогично содержит санкцию в виде административного приостановления деятельности, которая может быть наложена на юридических лиц в качестве альтернативы штрафру.

По нашему мнению, административное приостановление деятельности как вид административного наказания хозяйствующих субъектов - юридических лиц или индивидуальных предпринимателей может повлечь их полную финан- 
совую несостоятельность. В свою очередь, это не способствует фрормированию благоприятного делового климата в государстве и подлежит исключению из числа административных наказаний, которые могут быть назначены в отношении хозяйствующих субъектов. Однако, данное утверждение не означает, что авторы настоящей статьи выступают за отмену временного запрета деятельности (ст.27.16 КоАП РФ), предусмотренной в качестве меры обеспечения производства по делам об административных правонарушениях.

Сущность данной меры в соответствии с частью 1 статьи 27.16 КоАП РФ заключается во временном запрете деятельности, установленном на срок до рассмотрения дела судом или должностными лицами прекращении деятельности фрилиалов, представительств, структурных подразделений юридического лица, производственных участков, а также эксплуатации агрегатов, объектов, зданий или сооружений, осуществления отдельных видов деятельности (работ), оказания услуг. Временный запрет деятельности может применяться только в исключительных случаях, если это необходимо для предотвращения непосредственной угрозы жизни или здоровью людей, возникновения эпидемии, эпизоотии, заражения (засорения) подкарантинных объектов карантинными объектами, наступления радиационной аварии или техногенной катастрофы, причинения существенного вреда состоянию или качеству окружающей среды, для устранения допущенных нарушений, выразившихся в незаконном привлечении к трудовой деятельности в Российской Федерации иностранного гражданина или лица без гражданства, либо в несоблюдении установленных в соответствии с федеральным законом в отношении иностранных граждан, лиц без гражданства и иностранных организаций ограничений на осуществление отдельных видов деятельности, либо в нарушении правил привлечения иностранных граждан и лиц без гражданства к трудовой деятельности, осуществляемой на торговых объектах (в том числе в торговых комплексах), и если предотвращение указанных обстоятельств другими способами невозможно.

Данная мера применяется во внесудебном порядке. В соответствии с частями 1,4 статьи 23.31 КоАП РФ её уполномочены применять руководитель федерального органа исполнительной власти, осуществляющего федеральный государственный надзор в области промышленной безопасности, федеральный государственный надзор в области безопасности гидротехнических сооружений, государственный горный надзор, его заместители; руководители территориальных органов федерального органа исполнительной власти, осуществляющего федеральный государственный надзор в области промышленной безопасности, федеральный государственный надзор в области безопасности гидротехнических сооружений, государственный горный надзор, их заместители.

Согласно действующему КоАП РФ временный запрет деятельности может быть применён только в том случае, если за совершённое административное правонарушение может быть назначено административное наказание в виде административного приостановления деятельности. Следует также отметить, что статьи 27.16 и 27.17 КоАП РФ не устанавливают никаких конкретных сроков действия данной меры принуждения. 
Указанная мера в соответствии с положениями статьи 27.16 может действовать на срок до рассмотрения дела судом или должностными лицами. Срок временного запрета деятельности исчисляется с момента фрактического прекращения деятельности фрилиалов, представительств, структурных подразделений юридического лица, производственных участков, а также эксплуатации агрегатов, объектов, зданий или сооружений, осуществления отдельных видов деятельности (работ), оказания услуг.

Следует также отметить, что и административное приостановление деятельности, и временный запрет деятельности, по своей юридической природе, являются административно-пресекательными мерами государственного принуждения. В частности, Бахрах Д.Н., в своих публикациях писал: «в законодательстве, науке и на практике многие годы её считали мерой административного пресечения» [9, c.78]. Однако в действующем КоАП РФ административное приостановление деятельности отнесено к административнонаказательным мерам принуждения. В науке административного права административно-пресекательные меры рассматриваются как меры, ориентированные на принудительное прекращение противоправного деяния. Так, Ю.М. Козлов в качестве целевого назначения этих мер рассматривает «прекращение в принудительном порядке противоправных деяний и предотвращение их вредных последствий»[10, с.361].По мысли Л.Л. Попова и Ю.И. Мигачёва, административно-пресекательные меры направлены на немедленное принятие мер уполномоченными субъектами с целью пресечения противоправных действий. «Суть подобных мер, - пишут авторы, - несмотря на их многообразие, состоит в принудительном пре- кращении противоправных действий (деятельности) граждан, должностных лиц, организаций, нарушающих установленный порядок» [11, с.202].

Несмотря на то, что в действующем КоАП РФ меры государственного принуждения - временный запрет деятельности и административного наказания - административного приостановления деятельности различаются по правовому статусу, они имеют сходство как по форме выражения - временное прекращение функционирование определённого объекта, так и по цели применения - немедленное пресечение противоправных действий.

Кроме того, КоАП РФ содержит указание на исключительный, чрезвычайный характер применения указанных меры принуждения и административного наказания, которые могут быть применены в случае непосредственной угрозы жизни или здоровью людей, возникновения эпидемии, и т.д.

В юридической науке высказывается точка зрения о необходимости отказа от трактовки административного приостановления деятельности как меры наказания.

«Меру принуждения в форме административного приостановления деятельности, - пишет Косицин И.А, - по ее содержанию следует относить к мерам административного предупреждения и пресечения. При административном пресечении деятельности практически отсутствует карательное воздействие на субъект правонарушения, поскольку последний имеет возможность обратиться за сокращением срока приостановления его деятельности и получить его. В действии этой меры четко выражены две функции: предупреждение и пресечение» [12, с.47].

Отказ от административного приостановления деятельности, как вида 
административного наказания, содержащегося в главе 14 КоАП РФ, повлечёт пересмотр ряда положений ст. 27.16, частей 1, 4 статьи 23.31 КоАП РФ.

Полагаем, что нет необходимости жестко увязывать применение меры принуждения в виде временного запрета деятельности и обязательным содержанием в санкции вида наказания административного приостановления деятельности. Следовательно, необходимо пересмотреть положение ст. 27.16 КоАП РФ о том, что временный запрет деятельности может быть применён только в том случае, если за совершённое административное правонарушение может быть назначено административное наказание в виде административного приостановления деятельности.

Исключение из главы 14 КоАП РФ меры административного наказания административного приостановления деятельности позволит решить проблему судебного усмотрения при принятии решения о мере наказания в отношении хозяйствующего субъекта за совершение соответствующего правонарушения.

Однако насколько целесообразным выглядит юридическая «трансформация» административно-пресекательной меры государственного принуждения в административно-наказательную санкцию, зафиксированную в общей части КоАП РФ? Опасность такого подхода заключается в том, что перечень административных наказаний в КоАП РФ будет постоянно расширяться, что, в свою очередь, послужит предпосылкой для усиления репрессивной составляющей административного законодательства и создаст негативный фон для осуществления предпринимательской деятельности в Российской Федерации.

Важно отметить позицию, изложенную в Постановление Пленума ВАС РФ.
Пункт 20 данного Постановления содержит положение о том, что «при рассмотрении дел об оспаривании решений административных органов о приостановлении или аннулировании лицензии на право осуществления определенного вида деятельности судам необходимо учитывать, что приостановление (аннулирование) лицензии не является административным наказанием в смысле КоАП РФ, а представляет собой специальную предупредительную меру, непосредственно связанную со спецификой деятельности, при осуществлении которой могут затрагиваться конституционные права и свободы, а также права и законные интересы других лиц».

Кроме того, в проекте КоАП РФ (общая часть) (статья 4.2) в качестве нового вида наказания сформулировано лишение специального права либо специального разрешения (лицензии). Если лишение специального права права на управление транспортным средством, право на охоту административное наказание давно известное российскому административно-деликтному законодательству, то лишение специального разрешения (лицензии) является новым видом кодифицированной административно-наказательной санкции. Статья 4.10 проекта устанавливает, что лишение специального разрешения (лицензии) может быть назначено судом (часть 2 ст. 4.10) и заключается в его аннулировании (часть 6 статьи 4.10). Данная санкция известна отечественному административному праву. Она, в частности, содержится в отраслевом законодательстве, например, в Федеральном законе от 4 мая 2011 года N 99-Ф3 «О лицензировании отдельных видов деятельности» (ред. от 13.07.2015) (далее - Закон о лицензировании отдель- 
ных видов деятельности) [13]. Статья 20 указанного закона содержит механизм аннулирования лицензии у юридического лица в судебном порядке по заявлению лицензирующего органа [14]. Предложенный проект КоАП РФ (общая часть) чётко обозначил тенденцию расширения перечня административных наказаний, содержащихся в КоАП РФ, за счет мер административно-пресекательных санкций.

Кроме того, проект КоАП РФ (статья 4.2) формулирует также в качестве самостоятельного административного наказания ликвидацию юридического лица или прекращение деятельности в качестве индивидуального предпринимателя. Данный вид наказания является принципиально новым в административном законодательстве Российской Федерации, хотя сам институт ликвидации юридического лица давно известен гражданскому законодательству. Так, части 3, 6 статьи 61 Гражданского кодекса Российской Федерации (часть 1) устанавливает основания принудительной ликвидации юридических лиц вследствие признания государственной регистрации юридических лиц недействительной; в случае осуществления юридическим лицом деятельности без надлежащего разрешения (лицензии) либо при отсутствии обязательного членства в саморегулируемой организации или необходимого в силу закона свидетельства о допуске к определенному виду работ, выданного саморегулируемой организацией; в случае осуществления юридическим лицом деятельности, запрещенной законом, либо с осуществляемой с его нарушением; систематического осуществления общественной организацией, общественным движением, благотворительным и иным фондом, религиозной организацией деятельности, противоречащей уставным целям таких организаций; банкротства юридического лица.

В части 1 статьи 4.17 проекта КоАП РФ (общая часть) сорормулированы основания ликвидации юридического лица или прекращения деятельности в качестве индивидуального предпринимателя практически дословно совпадающие с основаниями ликвидации юридического лица, изложенными в пункте 2 статьи 61 ГК РФ: «осуществление юридическим лицом деятельности без надлежащего разрешения (лицензии) либо при отсутствии обязательного членства в саморегулируемой организации или необходимого в силу закона свидетельства о допуске к определенному виду работ, выданного саморегулируемой организацией» [8].

Таким образом, наблюдается тенденция не только юридической «трансформации» административно-пресекательных мер государственного принуждения в административно-наказательные, но юридическое заимствование гражданско-правовых оснований принудительной ликвидации юридического лица в административно-правовые основания. По сути, гражданскоправовой элемент института ликвидации юридического лица стал административно-правовой наказательной санкцией, в соответствии с положениями проекта КоАП РФ (общая часть).

Как можно разрешить проиллюстрированную проблему расширения перечня административных наказаний, зафиксированных в проекте КоАП РФ (общая часть)?

Полагаем, что содержащиеся в отраслевых законах меры государственного принуждения (например, приоста- 
новление (аннулирование)) лицензии, которые применяют субъекты административной юрисдикции в отношении юридических лиц, могут быть применены в качестве альтернативы административному наказанию в виде административного приостановления деятельности. Соответствующие меры государственного принуждения в отношении виновных юридических лиц могут быть применены в качестве дополнительных санкций, посредством внесения соответствующих фрормулировок в санкции отдельных статей КоАП РФ. Предлагается дополнить санкции соответствующих норм КоАП РФ, содержащихся в главе 14 КоАП РФ отсылками к соответствующим нормам отраслевых законов, содержащим специфические меры государственного реагирования принудительного характера. Например, Закон о лицензировании отдельных видов деятельности содержит механизм аннулирования лицензии у юридического лица в судебном порядке по заявлению лицензирующего органа (ч. 12. ст. 20 указанного Закона). Данная мера может быть применена в качестве дополнительной санкции, применительно к следующим статьям КоАП РФ:

1. часть 4 статьи 14.1 (осуществление предпринимательской деятельности с грубым нарушением условий, предусмотренных специальным разрешением (лицензией)).

2. часть 4 статьи 14.1.1 (осуществление деятельности по организации и проведению азартных игр в букмекерских конторах и тотализаторах с грубым нарушением условий, предусмотренных лицензией).

3. часть 2 статьи 14.1.2 (повторное совершение административного правонарушения, предусмотренного частью 1 настоящей статьи, (осуществление предпринимательской деятельности в области транспорта без лицензии)).

4. часть 4 статьи 14.1.2 (осуществление предпринимательской деятельности в области транспорта, за исключением автомобильного транспорта и городского наземного электрического транспорта, с грубым нарушением условий, предусмотренных лицензией).

\section{Библиография:}

1. Салищева Н.Г. О некоторых тенденциях развития законодательства об административной ответственности в России в современный период // Административное право и процесс. 2009. N 5. C. 5-12.

2. Салищева Н.Г. Проблемы правового регулирования института административной ответственности в Российской Федерации // Административное право и процесс. 2014. N 9. C. $9-22$.

3. Федеральный закон от 09.05.2005 N 45-Ф3 (ред. от 29.12.2012) «О внесении изменений в Кодекс Российской Федерации об административных правонарушениях и другие законодательные акты Российской Федерации, а также о признании утратившими силу некоторых положений законодательных актов Российской Федерации» // СЗ РФ, 09.05.2005, № 19, ст. 1752.

4. Письмо ВАС РФ от 27 июля 2004 г. № С8-4/уз-944 «О проекте фредерального закона № 71562-4 «О внесении изменений в Кодекс Российской Федерации об административных правонарушениях и другие законодательные акты Российской Федерации, а также о признании утратившими силу некоторых положений законодательства Российской Федерации» (по вопросу приостановления деятельности предпринимателей)» // Справочная правовая система Консультант Плюс. 
5. Постановление Пленума Верховного Суда Российской Федерации от 24 марта 2005 г. № 5 «О некоторых вопросах, возникающих при применении Кодекса Российской Федерации об административных правонарушениях» (ред. от 19.12.2013) // Бюллетень Верховного Суда РФ, № 6, 2005.

6. Постановление Пленума ВАС РФ от 02.06.2004 № 10 «О некоторых вопросах, возникших в судебной практике при рассмотрении дел об административных правонарушениях» // Вестник ВАС РФ, №8, 2004.

7. Постановление Пленума ВАС РФ от 10.11.2011 N 71 «О внесении изменений в некоторые Постановления Пленума Высшего Арбитражного Суда Российской Федерации, касающиеся рассмотрения арбитражными судами дел об административных правонарушениях, и признании утратившим силу Постановления Пленума Высшего Арбитражного Суда Российской Федерации от 20.06.2007 N 41 «О применении арбитражными судами статьи 14 Федерального закона «Об исполнительном производстве» в части регулирования сроков предъявления к исполнению постановлений органов (должностных лиц), уполномоченных рассматривать дела об административных правонарушениях» // Вестник ВАС РФ, № 1, январь, 2012.

8. Проект Федерального закона № 703192-6 «Кодекс Российской Федерации об административных правонарушениях (Общая часть)» (ред., внесенная в ГД ФС РФ, текст по состоянию на 20.01.2015) // СПС КонсультантПлюс.

9. Бахрах Д.Н. Вопросы системы административных наказаний // Полицейское право, № 1, 2008.

10. Козлов Ю.М. Административное право. М., 2005.

11. Административное право Российской Федерации: учебник для бакалавров / отв. ред. Л.Л. Попова. М., 2014.

12. Косицин И.А. Административное приостановление деятельности в системе мер административного принуждения // Омский научный вестник. № 5 (40). 2006.

13. Федеральный закон от 4 мая 2011 года N 99-Ф3 «О лицензировании отдельных видов деятельности» (ред. от 13.07.2015) // Российская газета», № 97, 06.05.2011.

14. Эскиндаров М.А. Систематизация мер государственного принуждения как фрактор устойчивого развития финансово-экономической деятельности // Финансовое право и управление. - 2015. - 2. - C. 110-113. DOI: 10.7256/2310-0508.2015.2.15639.

\section{References (transliterated):}

1. Salishcheva N.G. O nekotorykh tendentsiyakh razvitiya zakonodatel'stva ob administrativnoi otvetstvennosti v Rossii v sovremennyi period // Administrativnoe pravo i protsess. 2009. N 5. S. 5-12.

2. Salishcheva N.G. Problemy pravovogo regulirovaniya instituta administrativnoi otvetstvennosti v Rossiiskoi Federatsii // Administrativnoe pravo i protsess. 2014. N 9. S. 9 - 22.

3. Bakhrakh D.N. Voprosy sistemy administrativnykh nakazanii // Politseiskoe pravo, № 1, 2008.

4. Kozlov Yu.M. Administrativnoe pravo. M., 2005.

5. Kositsin I.A. Administrativnoe priostanovlenie deyatel'nosti v sisteme mer administrativnogo prinuzhdeniya // Omskii nauchnyi vestnik. № 5 (40). 2006.

6. Eskindarov M.A. Sistematizatsiya mer gosudarstvennogo prinuzhdeniya kak faktor ustoichivogo razvitiya finansovo-ekonomicheskoi deyatel'nosti // Finansovoe pravo i upravlenie. - 2015. - 2. C. 110-113. DOI: 10.7256/2310-0508.2015.2.15639. 